\title{
Change Detection using Deep Learning and Machine Learning Techniques for Multispectral Satellite Images
}

\author{
T. Vignesh, K. K. Thyagharajan, K. Ramya
}

\begin{abstract}
Change detection is used to find whether the changes happened or not between two different time periods using remote sensing images. We can use various machine learning techniques and deep learning techniques for the change detection analysis using remote sensing images. This paper mainly focused on computational and performance analysis of both techniques in the application of change detection.For each approach, we considered ten different kinds of algorithms and evaluated the performance. Moreover, in this research work, we have analyzed merits and demerits of each method which have used to change detection.
\end{abstract}

Keywords: Convolutional neural network (CNN), Image averaging and maximization, Discrete Cosine Transform, remote sensing

\section{INTRODUCTION}

There is a lot of development in remote sensing technology. Everyday a lot of remotely sensed data are produced by various satellites like landsat7, landsat8 LISS III etc. Change detection is very important to discover land changes in the same area for a period of time [1]. This can be used for various applications like urban expansion, disaster management, land cover object identification etc. Synthetic aperture radar (SAR) images are produced by sending a microwave signal sensors to the ground and receives the backscattered waves from the ground which is received by the receiver [2]. A microwave beam of $(0.3-30 \mathrm{~cm})$ is used. Convolutional neural network is part of Artificial Intelligence. It is a way of making the computers to take the decisions like human being. Convolutional neural network is an algorithm used to find patterns for a given dataset. Convolutional neural network are processed based on layers [3]. For example, if we are passing an image of car as input then the first layer identifies the dots and edges and the second layer identifies the tires, hood and other parts then, the third layer identifies the full car and give the output as car [4]. To do this the neural network has to be trained with similar images and to find the patterns in such a way that if similar pattern occurs in future it will recognize it based on

Revised Manuscript Received on November 27, 2019

* Correspondence Author

T.Vignesh , Saveetha School of Engineering, Saveetha Institute of Medical and Technical Sciences, Chennai, India.

Email: vigneshthangathurai@gmail.com

K.K.Thyagharajan, RMD Engineering College, Kavaraipettai, Chennai, India.Email: kkthyagharajan@yahoo.com

K.Ramya, Technical Leader, Altran, Chennai, India. Email ramya25kaliappan@gmail.com the past patterns learnt. Change detection can be done using different algorithms such as k-means clustering algorithm, generic algorithm etc [5]. Convolutional neural network can be used for general purposes like road traffic condition classification or medical purposes like diagnosing automated stroke lesion segmentation or commercial purposes like horror image recognition [6]. The following table 1 illustrates the various deep learning and machine learning techniques for change detection.

\section{DEEP LEARNING AND MACHINE LEARNING TECHNIQUES FOR CHANGE DETECTION}

\begin{tabular}{|c|c|c|c|c|}
\hline S.N & Method & $\begin{array}{c}\text { Datase } \\
\mathbf{t}\end{array}$ & Merits & Demerits \\
\hline 1 & $\begin{array}{c}\text { A } \\
\text { self-organizing } \\
\text { map and deep } \\
\text { neural network } \\
\text { (SOMDNCD) } \\
{[7]}\end{array}$ & $\begin{array}{l}\text { SAR } \\
\text { image }\end{array}$ & $\begin{array}{l}\text { Exhibits a lower } \\
\text { missed detection } \\
\text { rate in the SAR } \\
\text { image data set and } \\
\text { a more ideal false } \\
\text { alarm rate }\end{array}$ & $\begin{array}{c}\text { Accuracy rate } \\
\text { is reduced due } \\
\text { to noise } \\
\text { Interference }\end{array}$ \\
\hline 2 & $\begin{array}{l}\text { Kittler-Illingw } \\
\quad \text { orth } \\
\text { minimum-error } \\
\text { thresholding } \\
\text { algorithm [8] }\end{array}$ & $\begin{array}{c}\text { SAR } \\
\text { images }\end{array}$ & $\begin{array}{l}\text { This increases the } \\
\text { size of the change } \\
\text { class which in turn } \\
\text { improves the } \\
\text { accuracy of the } \\
\text { estimation of the } \\
\text { optimum } \\
\text { threshold }\end{array}$ & $\begin{array}{l}\text { The } \\
\text { background } \\
\text { information of } \\
\text { SAR images is } \\
\text { complex, and } \\
\text { the texture is } \\
\text { often less } \\
\text { obvious }\end{array}$ \\
\hline 3 & $\begin{array}{c}\text { K-Means } \\
\text { clustering [9] }\end{array}$ & $\begin{array}{c}\text { Multi } \\
\text { tempor } \\
\text { al } \\
\text { satellite } \\
\text { images }\end{array}$ & $\begin{array}{l}\text { Less prone to } \\
\text { errors caused } \\
\text { from the noise }\end{array}$ & $\begin{array}{l}\text { Thicker } \\
\text { boundaries of } \\
\text { the resultant } \\
\text { change map }\end{array}$ \\
\hline 4 & $\begin{array}{l}\text { Scale invariant } \\
\text { feature } \\
\text { transform }[10]\end{array}$ & $\begin{array}{c}\text { SAR } \\
\text { Images }\end{array}$ & $\begin{array}{l}\text { More precise } \\
\text { results and } \\
\text { exhibits stronger } \\
\text { robustness against } \\
\text { speckle noise }\end{array}$ & $\begin{array}{c}\text { Mathematicall } \\
\text { y complicated } \\
\text { and } \\
\text { computationall } \\
\text { y heavy }\end{array}$ \\
\hline 5 & $\begin{array}{c}\text { Two-level } \\
\text { clustering [11] }\end{array}$ & $\begin{array}{c}\text { SAR } \\
\text { Images }\end{array}$ & $\begin{array}{l}\text { This help to } \\
\text { discriminate the } \\
\text { intermediate } \\
\text { pixels, and works } \\
\text { better for the } \\
\text { overlap of the } \\
\text { changed and } \\
\text { unchanged classes } \\
\text { than a single FCM } \\
\text { clustering }\end{array}$ & $\begin{array}{l}\text { high time } \\
\text { complexity }\end{array}$ \\
\hline
\end{tabular}




\begin{tabular}{|c|c|c|c|c|}
\hline 6 & $\begin{array}{c}\text { K-means } \\
\text { clustering [12] }\end{array}$ & $\begin{array}{l}\text { SAR } \\
\text { Images }\end{array}$ & $\begin{array}{l}\text { differencing } \\
\text { method performs } \\
\text { better than the } \\
\text { single-channel } \\
\text { intensity band } \\
\text { ratio and the total } \\
\text { power ratio }\end{array}$ & $\begin{array}{l}\text { Difficult to } \\
\text { predict } \\
\text { K-Value. }\end{array}$ \\
\hline 7 & $\begin{array}{c}\text { Parallel binary } \\
\text { particle swarm } \\
\text { optimization } \\
{[13]}\end{array}$ & $\begin{array}{l}\text { multisp } \\
\text { ectral } \\
\text { image, } \\
\text { multite } \\
\text { mporal } \\
\text { images }\end{array}$ & $\begin{array}{c}\text { proposed } \\
\text { approach } \\
\text { effectively solves } \\
\text { the } \\
\text { change-detection } \\
\text { problem for the } \\
\text { small, medium } \\
\text { and large-scale } \\
\text { data sets. }\end{array}$ & $\begin{array}{l}\text { The disadvanta } \\
\text { ges of particle } \\
\text { swarm optimiz } \\
\text { ation (PSO) } \\
\text { algorithm are } \\
\text { that it is easy to } \\
\text { fall into local } \\
\text { optimum in } \\
\text { high-dimensio } \\
\text { nal space and } \\
\text { has a low } \\
\text { convergence } \\
\text { rate in the } \\
\text { iterative } \\
\text { process } \\
\end{array}$ \\
\hline 8 & $\begin{array}{c}\text { Genetic } \\
\text { algorithm [14] }\end{array}$ & $\begin{array}{l}\text { Advanc } \\
\text { ed } \\
\text { Synthet } \\
\text { ic } \\
\text { Apertur } \\
\text { e Radar } \\
\text { image }\end{array}$ & $\begin{array}{l}\text { The current } \\
\text { technology in } \\
\text { parallel } \\
\text { computing with } \\
\text { high-power } \\
\text { processors makes } \\
\text { the proposed } \\
\text { method feasible }\end{array}$ & $\begin{array}{c}\text { GA is time } \\
\text { consuming and } \\
\text { it is difficult for } \\
\text { larger } \\
\text { problems }\end{array}$ \\
\hline 9 & $\begin{array}{l}\text { The algorithm } \\
\text { exploits the } \\
\text { inherent } \\
\text { multiscale } \\
\text { structure of the } \\
\text { dual-tree } \\
\text { complex } \\
\text { wavelet } \\
\text { transform } \\
\text { (DT-CWT) } \\
\text { [15] }\end{array}$ & $\begin{array}{l}\text { multisp } \\
\text { ectral } \\
\text { images, } \\
\text { multite } \\
\text { mporal } \\
\text { images }\end{array}$ & $\begin{array}{c}\text { Robustness } \\
\text { against noise } \\
\text { interference under } \\
\text { various noise } \\
\text { types and noise } \\
\text { levels }\end{array}$ & $\begin{array}{c}\text { The increase in } \\
\text { the number of } \\
\text { scale } \mathrm{S} \text { will } \\
\text { also increase } \\
\text { the } \\
\text { change-detecti } \\
\text { on } \\
\text { performance at } \\
\text { the expense of } \\
\text { yielding larger } \\
\text { computational } \\
\text { load }\end{array}$ \\
\hline 10 & $\begin{array}{c}\text { Convolutional } \\
\text { neural } \\
\text { networks [16] }\end{array}$ & $\begin{array}{c}\text { DDM } \\
\text { images }\end{array}$ & $\begin{array}{l}\text { overall improved } \\
\text { accuracy and } \\
\text { fewer parameters } \\
\text { in the network }\end{array}$ & $\begin{array}{l}\text { Interference of } \\
\text { the speckle } \\
\text { noise }\end{array}$ \\
\hline 11 & $\begin{array}{c}\text { Convolutional } \\
\text { neural network } \\
{[17]}\end{array}$ & $\begin{array}{l}\text { Any } \\
\text { face } \\
\text { images }\end{array}$ & $\begin{array}{l}\text { CNN processors } \\
\text { will have better } \\
\text { energy efficiency }\end{array}$ & $\begin{array}{c}\text { Cannot work } \\
\text { on more } \\
\text { computational } \\
\text { loads }\end{array}$ \\
\hline 12 & $\begin{array}{c}\text { Convolutional } \\
\text { neural network } \\
{[18]}\end{array}$ & $\begin{array}{l}\text { video } \\
\text { surveill } \\
\text { ance } \\
\text { data }\end{array}$ & $\begin{array}{c}\text { Traffic condition } \\
\text { classification } \\
\text { based on } \\
\text { convolutional } \\
\text { neural networks } \\
\text { and texture } \\
\text { interpretation of } \\
\text { the scene correctly } \\
\text { determines LOS } \\
\text { for almost } 90 \% \text { of } \\
\text { the tested images }\end{array}$ & $\begin{array}{l}\text { The images } \\
\text { from these } \\
\text { cameras } \\
\text { contain a } \\
\text { significant } \\
\text { number of } \\
\text { occluding } \\
\text { vehicles which } \\
\text { impairs the } \\
\text { classification }\end{array}$ \\
\hline 13 & $\begin{array}{c}\text { Markov } \\
\text { random field } \\
\text { framework } \\
{[19]}\end{array}$ & $\begin{array}{l}\text { remote } \\
\text { sensing } \\
\text { images }\end{array}$ & $\begin{array}{c}\text { Its weighting } \\
\text { mechanism } \\
\text { implemented at } \\
\text { both the pixel and } \\
\text { the image levels to } \\
\text { handle the } \\
\text { reliability of the } \\
\text { results provided } \\
\text { by each } \\
\text { thresholding } \\
\text { algorithm making } \\
\text { up the considered } \\
\text { level }\end{array}$ & $\begin{array}{l}\text { The simple } \\
\text { MV fusion rule } \\
\text { appears more } \\
\text { sensitive to } \\
\text { fusion } \\
\text { scenarios with } \\
\text { misleading }\end{array}$ \\
\hline
\end{tabular}

\begin{tabular}{|c|c|c|c|c|}
\hline 14 & $\begin{array}{c}\text { Convolutional } \\
\text { neural network } \\
(\mathrm{CNN}) \text {, deep } \\
\text { learning, } \\
\text { recurrent } \\
\text { neural network } \\
\text { (RNN) [20] }\end{array}$ & $\begin{array}{l}14 \mathrm{TS} \\
\text { data } \\
\text { sets } \\
\text { from } \\
\text { the } \\
\mathrm{UCR} \\
\text { TS } \\
\text { reposito } \\
\text { ry } \\
\text { archive }\end{array}$ & $\begin{array}{l}\text { This can be } \\
\text { applied to a large } \\
\text { variety of TSC } \\
\text { tasks across } \\
\text { different domains }\end{array}$ & $\begin{array}{c}\text { The accuracy } \\
\text { of unbalanced } \\
\text { and multiclass } \\
\text { dataset might } \\
\text { not be } \\
\text { sufficient for } \\
\text { calculating its } \\
\text { performance }\end{array}$ \\
\hline 15 & $\begin{array}{c}\text { Artificial } \\
\text { intelligence, } \\
\text { convolutional } \\
\text { neural } \\
\text { network, } \\
\text { recurrent } \\
\text { neural network } \\
{[21]}\end{array}$ & & $\begin{array}{l}\text { This proposed } \\
\text { network model is } \\
\text { more accurate and } \\
\text { efficient in } \\
\text { classifying blood } \\
\text { cell images }\end{array}$ & $\begin{array}{c}\text { The } \\
\text { classification } \\
\text { of a single cell } \\
\text { image takes } \\
\text { about } 3.8 \\
\text { seconds, which } \\
\text { is clinically too } \\
\text { slow so it needs } \\
\text { good hardware } \\
\text { resources }\end{array}$ \\
\hline 16 & $\begin{array}{c}\text { Deep learning, } \\
\text { stroke lesion } \\
\text { segmentation, } \\
\text { residual } \\
\text { network } \\
\text { (ResNet), } \\
\text { convolutional } \\
\text { neural network } \\
\text { (CNN), fully } \\
\text { convolutional } \\
\text { network (FCN) } \\
\text { [22] }\end{array}$ & $\begin{array}{c}\text { A } \\
\text { public } \\
\text { data set, } \\
\text { i.e., } \\
\text { ISLES2 } \\
\text { 015-SI } \\
\text { SS }\end{array}$ & $\begin{array}{l}\text { it presents very } \\
\text { low false } \\
\text { negatives }\end{array}$ & $\begin{array}{l}\text { This research } \\
\text { did not include } \\
\text { detection of } \\
\text { hemorrhagic } \\
\text { transformation, } \\
\text { which is a } \\
\text { complication } \\
\text { of ischemic } \\
\text { stroke }\end{array}$ \\
\hline 17 & $\begin{array}{l}\text { Deep neural } \\
\text { network [23] }\end{array}$ & $\begin{array}{l}\text { JPEG2 } \\
000 \text { and } \\
\text { optical } \\
\text { space-b } \\
\text { orne } \\
\text { image }\end{array}$ & $\begin{array}{l}\text { less detection time } \\
\text { and achieves } \\
\text { higher detection } \\
\text { accuracy }\end{array}$ & $\begin{array}{c}\text { Might not give } \\
\text { same accuracy } \\
\text { for all types of } \\
\text { images }\end{array}$ \\
\hline 18 & $\begin{array}{c}\text { Convolutional } \\
\text { neural } \\
\text { networks } \\
\text { (CNNs), } \\
\text { deformable } \\
\text { convolution } \\
{[24]}\end{array}$ & $\begin{array}{l}\text { Hypers } \\
\text { pectral } \\
\text { image } \\
(\text { HIS })\end{array}$ & $\begin{array}{c}\text { The experimental } \\
\text { results } \\
\text { demonstrate that } \\
\text { DHCNet } \\
\text { performs better } \\
\text { than several } \\
\text { well-known HSI } \\
\text { classification }\end{array}$ & $\begin{array}{l}\text { Thicker } \\
\text { boundaries of } \\
\text { the resultant } \\
\text { change map }\end{array}$ \\
\hline 19 & $\begin{array}{c}\text { Learning } \\
\text { algorithm [25] }\end{array}$ & $\begin{array}{l}\text { Two } \\
\text { sets of } \\
\text { test } \\
\text { images, } \\
\text { the first } \\
\text { for the } \\
\text { singlesc } \\
\text { ale case } \\
\text { and the } \\
\text { second } \\
\text { for the } \\
\text { multisc } \\
\text { ale case }\end{array}$ & $\begin{array}{l}\text { This algorithm is } \\
\text { able to accurately } \\
\text { detect objects in } \\
\text { complex images }\end{array}$ & $\begin{array}{c}\text { multiscale } \\
\text { detection } \\
\text { problem is } \\
\text { clearly harder } \\
\text { than the } \\
\text { single-scale } \\
\text { one }\end{array}$ \\
\hline 20 & $\begin{array}{c}\text { Digital surface } \\
\text { model (DSM) } \\
\text { generation, } \\
\text { dynamic } \\
\text { programming } \\
{[26]}\end{array}$ & $\begin{array}{c}\text { satellite } \\
\text { stereosc } \\
\text { opic } \\
\text { images }\end{array}$ & $\begin{array}{l}\text { Better compared } \\
\text { to the classical } \\
\text { visual image } \\
\text { analysis }\end{array}$ & $\begin{array}{c}\text { The present } \\
\text { processing } \\
\text { flow cannot be } \\
\text { applied }\end{array}$ \\
\hline
\end{tabular}

Table 1: Deep learning and machine learning techniques for Change detection

\section{RESULT ANALYSIS}

In the side of deep learning, we considered, convolutional neural network $(\mathrm{CNN})$, recurrent neural network (RNN), Faster RNN, deep belief network (DBN) and stacked auto encoder (SAE). 
In the side if machine learning, we considered, back propagation(BP) algorithm, K-means clustering (K-means), fuzzy k-means clustering, C-means clustering and support vector machine (SVM). The main problem we found with images used for change detection is the noise interference due to this the accuracy of the output is reduced. Most of the change detection was done with multitemporal images and Multispectral images. The algorithms used for finding change detection is Deep neural network (DNN), K-means clustering, Kittler-Illingworth minimum-error thresholding algorithm, Two-level clustering, parallel binary particle swam optimization, generic algorithm etc. In deep neural network, they used around 50 hidden layers so the missed detection rate is lower. In supervised nonparametric technique based on the compound classification rule the accuracy rate was more than performance oriented congestion control and can still increase the accuracy. By using k-means clustering the errors occurring due to noise can be reduced but the foundries in the change map are thick so that accuracy is reduced. Change detection using generic algorithm can be used but it needs high processing speed and the method is time consuming and it's also not suitable for lager problems. The convolutional neural network can be used to find Sea Ice Sensing from GNSS-R Data the data set used is DMM images but the interference of speckle noise is high. Multi-Scale Deep Reinforcement Learning for Real-Time 3D-Landmark Detection in multispectral images can also be done using deep learning doing so they were able to increase the accuracy rate by $20 \%$. Table 3 illustrates the Classification accuracy analysis of deep learning networks vs machine learning algorithms.

The sample data set is first feed to the neural network in Wheel Defect Detection. With Machine Learning different types of defect is loaded as data set and the pattern is reorganized by the neural network based on the pattern that we got from the given dataset. This Compressed-Domain Ship Detection on Space borne Optical Image the deep neural network is used to achieve less detection time with high accuracy but this cannot give the same accuracy for all kinds of images. It can give more accurate results for optical Space borne images. The main cause for reduction in accuracy of the change detection in various algorithms is because of the impacts caused due to speckle noise. The accuracy of an the algorithms vary from one type of input data images to another type of input data image, i.e the accuracy of algorithms may vary for different satellite images. When compared to machine learning algorithms, deep learning algorithms produced good results.

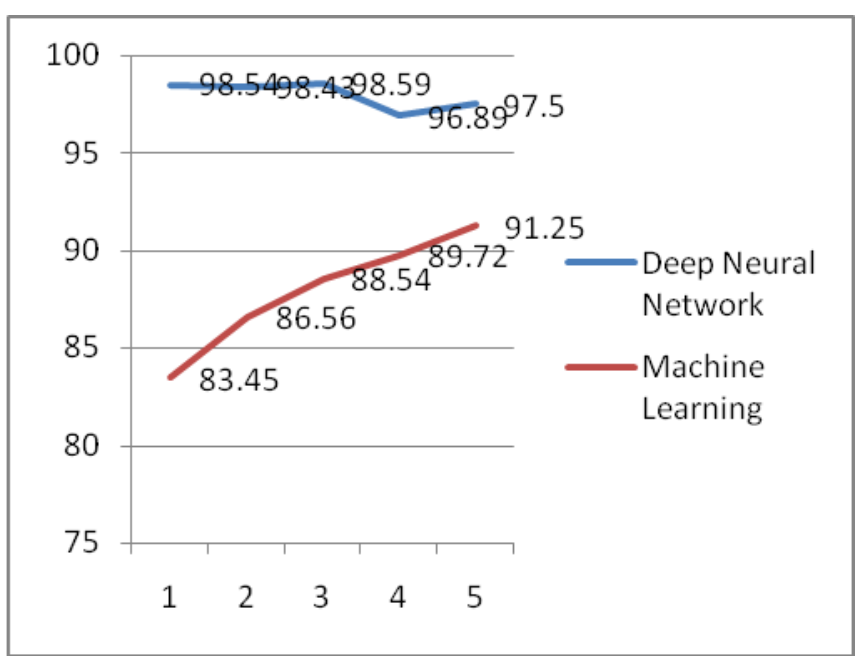

\section{CONCLUSSION}

Change detection using multispectral images is very challenging task. To identify the changes from multispectral images we used deep learning algorithms and machine learning algorithms. While can be further improved by predicting the defect prior. .Multi-instance learning is done to recognize the pattern horror image reorganization will identify the image based on the dataset we gave as input.

In using machine learning algorithms, feature extraction phase is needed before find out the change detection. Feature extraction phase is used to boost up the accuracy of multispectral images. But, while using deep learning algorithms, separate feature extraction phase is not needed. Classification accuracy is based on which algorithms used to identify the changes and the also based on the resolution of the images. We have concluded that, deep learning algorithms produced better accuracy than machine learning techniques.

\section{REFERENCES}

1. Lorenzo Bruzzone, and Sebastiano B. Serpico, "An Iterative Technique for the Detection of Land-Cover Transitions in Multitemporal Remote-Sensing Images"IEEE Transactions on Geoscience and Remote Sensing, vol. 35, no. 4, pp.858-867 July 1997.

2. M.N. Sumaiya R. Shantha Selva Kumari "Unsupervised Edge Enhancement algorithm for SAR Images using Exploitation of Wavelet Transform Coefficients" 2014 International Conference on Communication and Network Technologies (ICCNT).

3. Jun Lu, Jonathan Li, Gang Chen, Linjun Zhao, Boli Xiong, and Gaoyao Kuang, Member, IEEE "Improving Pixel-Based Change Detection Accuracy Using an Object-Based Approach in Multitemporal SAR Flood Images"IEEE Journal of Selected Topics in Applied Earth Observations and Remote Sensing, vol. 8, no. 7 pp.3486-3496, July 2015

4. Yuqi Tang, Xin Huang, and Liangpei Zhang "Fault-Tolerant Building Change Detection from Urban High-Resolution Remote Sensing Imagery” IEEE Geoscience and Remote Sensing Letters, vol. 10, no. 5,pp.1060-1064 Sep 2013. 
5. Turgay Celik and Kai-Kuang Ma, "Multitemporal Image Change Detection Using Undecimated Discrete Wavelet Transform and Active Contours" IEEE Transactions on Geoscience and Remote Sensing, vol. 49, no. 2,pp.706-716 ,Feb 2011.

6. Turgay Celik "Multiscale Change Detection in Multitemporal Satellite Images" IEEE Geoscience and Remote Sensing Letters, vol. 6, no. 4,PP.820-824,Oct 2009.

7. Ruliang Xiao, Runxi Cui , Mingwei Lin , Lifei Chen ,Youcong Ni1, and Xinhong Lin, "SOMDNCD: Image Change Detection Based on Self-Organizing Maps and Deep Neural Networks", DOI: 0.1109/ACCESS.2018.2849110,2018.

8. Yifang Banand Osama A.Yousif "Multitemporal Spaceborne SAR Data for Urban Change Detection in China" IEEE Journal of Selected Topics in Applied Earth Observations and Remote Sensing, vol. 5, no. 4, pp.1087-1094 ,Aug2012.

9. Turgay Celik "Unsupervised Change Detection in Satellite Images Using Principal Component Analysis and k-Means Clustering" IEEE Geoscience and Remote Sensing Letters, vol. 6, no. 4,pp.772-776 ,Oct 2009.

10. Yan Wang, Lan Du and Hui Dai "Unsupervised SAR Image Change Detection Based on SIFT Keypoints and Region Information" IEEE Geoscience And Remote Sensing Letters, vol. 13, no. 7,pp.931-935 ,July 2016.

11. Heng-Chao Li, Turgay Celik, Nathan Longbotham and William J. Emery,' Gabor Feature Based Unsupervised Change Detection of Multitemporal SAR Images Based on Two-Level Clustering" IEEE Geoscience and Remote Sensing Letters, vol. 12, no. 12,PP.2458-2462,Dec 2015.

12. Debanshu Ratha, Shaunak De, Student Member, Turgay Celik, Member, and Avik Bhattacharya, Senior Member, IEEE "Change Detection in Polarimetric SAR Images Using a Geodesic Distance Between Scattering Mechanisms" IEEE Geoscience and Remote Sensing Letters, vol. 14, no. 7,PP.1066-1070 ,July 2017.

13. Huseyin Kusetogullari, Amir Yavariabdi, and Turgay Celik, "Unsupervised Change Detection in Multitemporal Multispectral Satellite Images Using Parallel Particle Swarm Optimization" IEEE Journal of Selected Topics in Applied Earth Observations And Remote Sensing, vol. 8, no. 5,PP.2151-2164 ,May 2015.

14. Turgay Celik "Change Detection in Satellite Images Using a Genetic Algorithm Approach" IEEE Geoscience and Remote Sensing Letters, v. 7ol, no. 2,PP.386-390,April 2010

15. Turgay Celik and Kai-Kuang Ma,"Unsupervised Change Detection for Satellite Images Using Dual-Tree Complex Wavelet Transform" IEEE Transactions on Geoscience and Remote Sensing, v. ol48, no. 3,pp.1199-1210 ,March 2010.

16. Qingyun Yan and Weimin Huang, "Sea Ice Sensing From GNSS-R Data Using Convolutional Neural Networks" IEEE Geoscience and Remote Sensing Letters, vol. 15, no. 10,pp. 1510-1514, Oct 2018.

17. Kyeongryeol Bong,Sungpill Choi,Changhyeon Kim,Hoi-Jun Yoo "Low-Power Convolutional Neural Network Processor for a Face-Recognition System" pp.30-38

18. Jian Zhu, Leyuan Fang and Pedram Ghamisi , "Deformable Convolutional Neural Networks for Hyperspectral Image Classification” IEEE Geoscience and Remote Sensing Letters, vol. 15, no. 8 pp.1254--1258, Aug 2018.

19. Farid Melgani, and Yakoub Bazi, "Markovian Fusion Approach to Robust Unsupervised Change Detection in Remotely Sensed Imagery" IEEE Geoscience and Remote Sensing Letters, vol. 3, no. 4, pp.457-461, Oct 2006.

20. Sangdi Lin and George C. Runger "GCRNN: Group-Constrained Convolutional Recurrent Neural Network" IEEE Transactions on Neural Networks and Learning Systems, vol. 29, no. 10,pp.4709-4718,Oct 20184709

21. Gaobo Liang, Huichao Hong, Weifang Xie, And Lixin Zheng”Combining Convolutional Neural Network With Recursive Neural Network for Blood Cell Image Classification”,pp.36188-36197, 2018.

22. Zhiyang Liu ,Chen Cao, Shuxue Ding, , Zhiang Liu, Tong Han, And Sheng Liu“"Towards Clinical Diagnosis: Automated Stroke Lesion Segmentation on Multi-Spectral MR Image Using Convolutional Neural Network",pp.57006-57016, 2018.

23. Jiexiong Tang, Chenwei Deng, Guang-Bin Huangand Baojun Zhao,"Compressed-Domain Ship Detection on Spaceborne Optical Image Using Deep Neural Network and Extreme Learning Machine" IEEE Transactions on Geoscience and Remote Sensing, vol. 53, no. 3,pp.1174-1185 ,March 2015.
24. Florin-Cristian Ghesu, Bogdan Georgescu, Yefeng Zheng, ,Sasa Grbic, Andreas Maier, Joachim Hornegger, and Dorin Comaniciu "Multi-Scale Deep Reinforcement Learning for Real-Time 3D-Landmark Detection in CT Scans" IEEE Transactions on Pattern Analysis and Machine Intelligence, vol. 41, no. 1 pp.176-189, Jan 2019

25. Shivani Agarwal, Aatif Awan, and Dan Roth,"Learning to Detect Objects in Images via a Sparse, Part-Based Representation” IEEE Transactions on Pattern Analysis and Machine Intelligence, vol. 26, no. 11,pp: 1475-1490,Nov 2004

26. Cyrielle Guerin, Renaud Binet, and Marc Pierrot-Deseilligny"Automatic Detection of Elevation Changes Differential DSM Analysis: Application to Urban Areas" IEEE Journal of Selected Topics in Applied Earth Observations and Remote Sensing, vol. 7, no. 10, pp.4020-4037,Oct 2014.

\section{AUTHORS PROFILE}

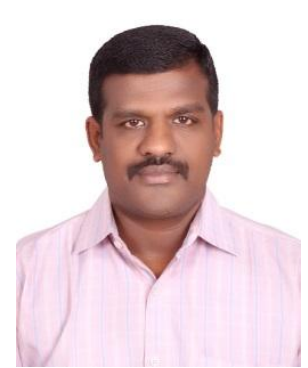

T.Vignesh received his M.Sc (Computer Science) and M.Tech (CIT) degree from Manonmaniam Sundaranar University, Tirunelveli, India in the year of 2006 and 2011 respectively. He also, obtained his doctoral degree from Manonmaniam Sundaranar University, Tirunelveli, India in the year of 2019. He is having around 9 years of teaching experience in various engineering college in Tamilnadu and 3 years industry experience. He has published more than 15 research papers in National and International journals and conferences. His research area includes Computer Vision, Image processing and Pattern recognition. He is a lifetime member of ISTE, IAENG, and IACSIT

E-Mail: vignesht.sse@ saveetha.com, vigneshthangathurai@gmail.com 